\title{
Application of Atomic Force Microscopy Methods for Testing the Surface Parameters of Coatings of Medical Implants
}

\author{
V. A. Klimenov, S. I. Tverdokhlebov, E. N. Bol'basov, E. V. Shesterikov, \\ V. A. Novikov, and T. L. Volokitina \\ National Research Tomsk Polytechnic University, pr. Lenina 30, Tomsk, 634050 Russia \\ Nanoelektronika Scientific and Educational Center, National Research Tomsk Polytechnic University \\ E-mail:klimenov@tpu.ru; tverd@tpu.ru; bolb@sibmail.com; evgen@micran.ru; Novikovvadim@ail.ru; \\ tatyanavolokitina@gmail.com
}

\begin{abstract}
Atomic force microscopy methods are used to study calcium phosphate coatings that are formed on surfaces of various materials, which are used in medicine, by radio-frequency magnetron sputtering of a hydroxyapatite target. The roughness parameters and values of the surface potentials of metal, polymer, and hybrid substrates are determined in a semicontact regime. Calcium phosphate coatings increase the roughness of surfaces of polymer and metal materials, thus presenting a stimulating factor for the attachment and proliferation of osteogenic cells. Using the Kelvin method, it is shown that calcium phosphate coatings change the surface potential of substrates.
\end{abstract}

Keywords: atomic force microscopy, surface potential, roughness, calcium phosphates, coatings.

\section{INTRODUCTION}

At present, one of the most promising classes of materials for biology and medicine includes composite and hybrid substances that consist of polymer or metal substrates with calcium phosphate coatings, which are produced by ion-plasma methods, in particular, magnetron sputtering of a calcium phosphate target $[1-3]$.

Radio-frequency magnetron sputtering (RFMS) is widely used in microelectronics for depositing films with complex chemical compositions without changes in their stoichiometry. The method is based on material sputtering in a vacuum due to the bombardment of the target surface by ions of a working gas (mainly argon), which are produced in anomalous glow discharge plasma when a magnetic field is applied to it [4]. In this case, the problem of biocompatibility of hybrid and polymer materials is quite urgent in medical material science and engineering of biological tissues.

When an implant is integrated with living tissues, a special role is played by its surface [5], whose important characteristics are the roughness parameters of the implant surface that determine the possibility of integration of tissues with the surface of an implanted device [6]. At the same time, some authors point to the electrical characteristics of the surface of the implanted device and show the key role of bioelectrical signalization on the processes of migration, proliferation, and differentiation of cells [7, 8]. Therefore, the problem of studying the properties of hybrid surfaces is urgent.

Modern technologies allow using the unique possibilities for studying the properties of surfaces. The intensive development of the atomic force microscopy (AFM) methods made it possible to obtain information on the most important characteristics of surfaces, such as the relief, electrical properties, and mechanical properties at the micro- and nanoscale. The most important advantages of this method are the relative simplicity of the preparation of a specimen for measurements and the high sensitivity and information content of the AFM methods. The latter is especially important in studies aimed at obtaining information on polymer, composite, and hybrid biomaterials [9].

This study was aimed at the investigation of properties of metal, polymer, and hybrid surfaces at the microscale using AFM methods. 


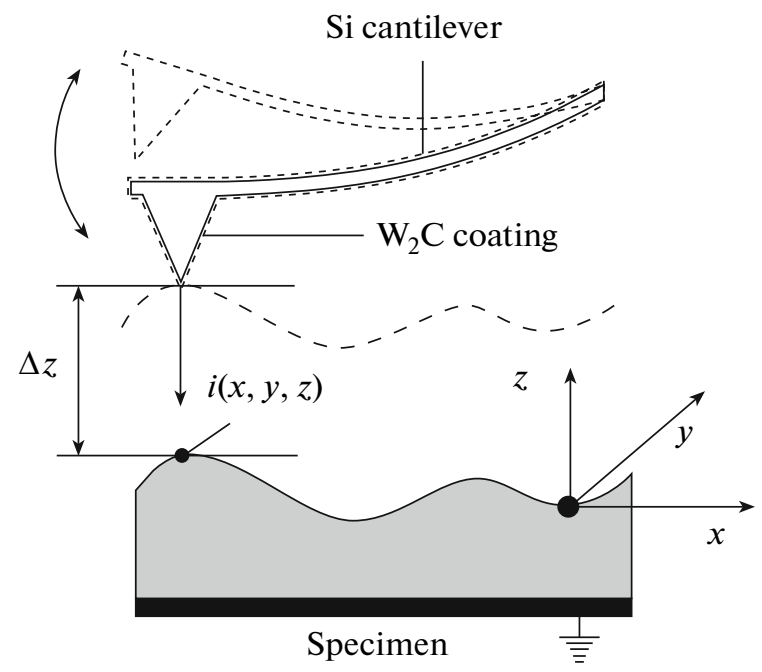

Fig. 1. Schematic drawing of the operation of an AF microscope in the double-pass regime.

\section{MATERIALS AND METHODS}

Several types of specimens, which are conventionally divided into groups I, II, III, and IV, were prepared for studying the properties of metal, polymer, and hybrid surfaces at the microscale by the AFM methods. The specimens of group I were plates of the BT-6 titanium alloy with dimensions of $20 \times 20 \times 3 \mathrm{~mm}$, which were first mechanically polished using GOI paste.

Specimens of group II were prepared similarly to those of group I. In this case, one of the sides of a specimen was coated with a calcium phosphate (CP) coating, which was formed by the method of RF magnetron sputtering of a hydroxyapatite target. The CP coating was deposited using a Cathode $1 \mathrm{M}$ industrial instrument, whose chamber contained a standard RF magnetron source powered by an RF generator at a maximum power of $4 \mathrm{~kW}$ and an operating frequency of $13.56 \mathrm{MHz}$. The following technological conditions were chosen for depositing CP coatings: a preliminary pressure in the chamber of $5 \times 10^{-5} \mathrm{~Pa}$; an operating $\mathrm{Ar}$ and $\mathrm{O}_{2}$ pressure of $3 \times 10^{-1} \mathrm{~Pa}$; a specific $\mathrm{RF}$ power of $\sim 20 \mathrm{~W} / \mathrm{cm}^{2}$; and a deposition time of $2 \mathrm{~h}$. In order to determine the specimen thickness, a part of the substrate was masked so that a coatingsubstrate interface could be formed. The coating thicknesses were determined on a Talysurf 5 mechanical profilometer (Tyler-Hobson, England) by the step method. The thickness of the formed CP coating was $0.8 \pm 0.02 \mu \mathrm{m}$ for the selected sputtering parameters.

The specimens of group III were prepared similarly to those of group I. In this case, one of the sides of a specimen was coated with an acetone solution of a copolymer of tetrafluoroethylene with vinyliden fluoride (TFE/VDF) by the pneumatic deposition method. A part of the specimen was masked to form a coating-substrate interface. The specimens with the deposited polymer coatings were then placed in an ITM 50.1100 chamber-type electric furnace (ITM, Tomsk), in which, in order to remove the remainder solvent and finally form a coating, the specimens were heated to $T=200^{\circ} \mathrm{C}$. The thicknesses of coatings were determined on a Talysurf 5 mechanical profilometer by the step method. The thickness of the formed polymer coatings was $5 \pm 0.4 \mu \mathrm{m}$.

Specimens of group IV were prepared similarly to those of group III. After this, the surface of the formed TFE/VDF polymer was modified by forming a CP coating by the RFMS method in the same technological regimes as the specimens of group II. For the selected sputtering parameters, the thickness of the formed CP coating was $0.8 \pm 0.02 \mu \mathrm{m}$.

The surfaces of specimens were investigated using a Solver-HV (NT-MDT) industrial atomic force (AF) microscope, which allows measurements of the surface relief, the surface potential distribution, and its phase contrast $[9,10]$. Measurements were performed in air under normal conditions in the semicontact operating regime using the two-pass technique.

Figure 1 shows a schematic diagram of the AF microscope operation in the two-pass regime. The operation in the semicontact regime was performed using NSG11 cantilevers with a $10-\mathrm{nm}$ radius of the probe tip curvature and a concentration of the doping impurity of $5 \times 10^{20} \mathrm{~cm}^{-3}$. 
Operation in the semicontact regime implies vibrations of the cantilever tip at the beam resonance frequency $\omega_{z}$. The two-pass technique provides the double passage (scanning) of one and the same sweep line with the tip. During the first passage, mechanical vibrations of the cantilever at the resonance frequency $\omega_{z}$ are excited by piezoelectric elements. The surface relief (coordinates of the $i$ th point of the surface $i(x$, $y, z)$ ) of the specimen is measured in response to a feedback signal, which is determined by a shift of the cantilever tip in the $(x, y)$ plane and a change in its vibration amplitude $A_{i z}\left(c o_{z}\right)$ along the $z$ axis at the moment the tip touches the surface.

Simultaneously with the construction of an image of the spatial surface relief during the first passage, an image of the surface phase contrast is constructed. During the surface scanning in the semicontact regime, the vibration phase $\theta$ is periodically measured upon each collision of the cantilever tip with the surface, which is determined by the interaction of the tip with the surface substance. The phase-contrast surface image is the distribution of the change in the phase $\Delta \theta$ in the $(x, y)$ plane. The change in $\Delta \theta$ is determined by different properties of surface areas with which the tip is in contact (microhardness, ductility, plasticity, etc.). In practice, this reflects changes in the surface phase composition. On a 2D image of the phase contrast, equal changes in $\Delta \theta$ (phase composition uniformity) are characterized by the same gray level. Thus, the gray-level distribution on the $(x, y)$ plane yields a qualitative pattern of the spatial distribution of the physical properties of a surface.

During the repeated pass of the cantilever (after measuring the spatial relief and the phase contrast), the surface potential relief is measured. For this purpose, the cantilever tip is lifted by a distance $\Delta z$ above the surface. In this case, vibrations of the tip are excited by applying an alternating voltage (signal) directly to the probe-specimen system. The alternating-signal frequency is taken equal to the resonance frequency $\omega_{z}$, which allows selection and measurement of only the electric component of the force $F_{z}$ acting between the specimen and cantilever.

The electric interaction force $F_{i z}$ between the $i$ th point of the specimen surface and the cantilever tip is determined by the gradient of the energy $E$ stored by the capacitance $C_{i}\left(E=C_{i} U_{i}^{2} / 2\right)$ of this system:

$$
F_{z, i}=-\frac{\partial E}{\partial z}=-\frac{1}{2} U_{i}^{2} \frac{\partial C}{\partial z},
$$

where $U_{i}(z)$ is the potential difference between the $i$ th point of the surface and the cantilever, which includes the surface potential $\varphi_{i}(x, y)$ relative to the grounded contact, a weak external alternating signal with an amplitude $U_{1}$ and a frequency $\omega_{z}$, and a constant (compensating) voltage $U_{0}$ :

$$
U=U_{0}-\varphi_{i}(x, y)+U_{i} \sin \left(w_{z} t\right) .
$$
force:

By substituting (2) into (1), it is easy to select the measured harmonic component of the interaction

$$
F_{z, i}\left(\omega_{z}\right)=-\frac{1}{2}\left\{\left[U_{0}-\varphi_{i}(x, y)\right] U_{1} \sin \left(\omega_{z} t\right) \frac{\partial C}{\partial z} .\right.
$$

Because $d \mathrm{C} / d z$ substantially increases with a decrease in the distance, the optimal condition for performing measurements is $\Delta z<r$. Note that the surface was scanned at a fixed number of steps (points, pixels) $N=256 \times 256$ regardless of the scanned area; the obtained AFM images were processed using the Gwiddion 2.25 software complex.

For all types of the investigated specimens, images of the surface relief, phase contrast, and surface potential were constructed and the following surface-roughness parameters were determined: the mean arithmetic deviation of the surface profile $R a$; the profile irregularity height over ten points $R z$; the maximum height $P t$ of the profile roughness; the average maximum depth of roughness valleys $R v m$; the average maximum height of roughness peaks $R p m$; the mean arithmetic deviation of the potential profile $\varphi_{a}$; the mean value of the surface potential $U_{\mathrm{m}}$; the maximum value of the surface potential $U_{\max }$; and the minimum value of the surface potential $U_{\text {min }}$.

\section{RESULTS AND DISCUSSION}

Figure 2 shows AFM images of the surface relief (a), phase contrast (b), and potential relief (c) for specimens of group I. A system of differently directed scratches, which are traces of the mechanical treat- 

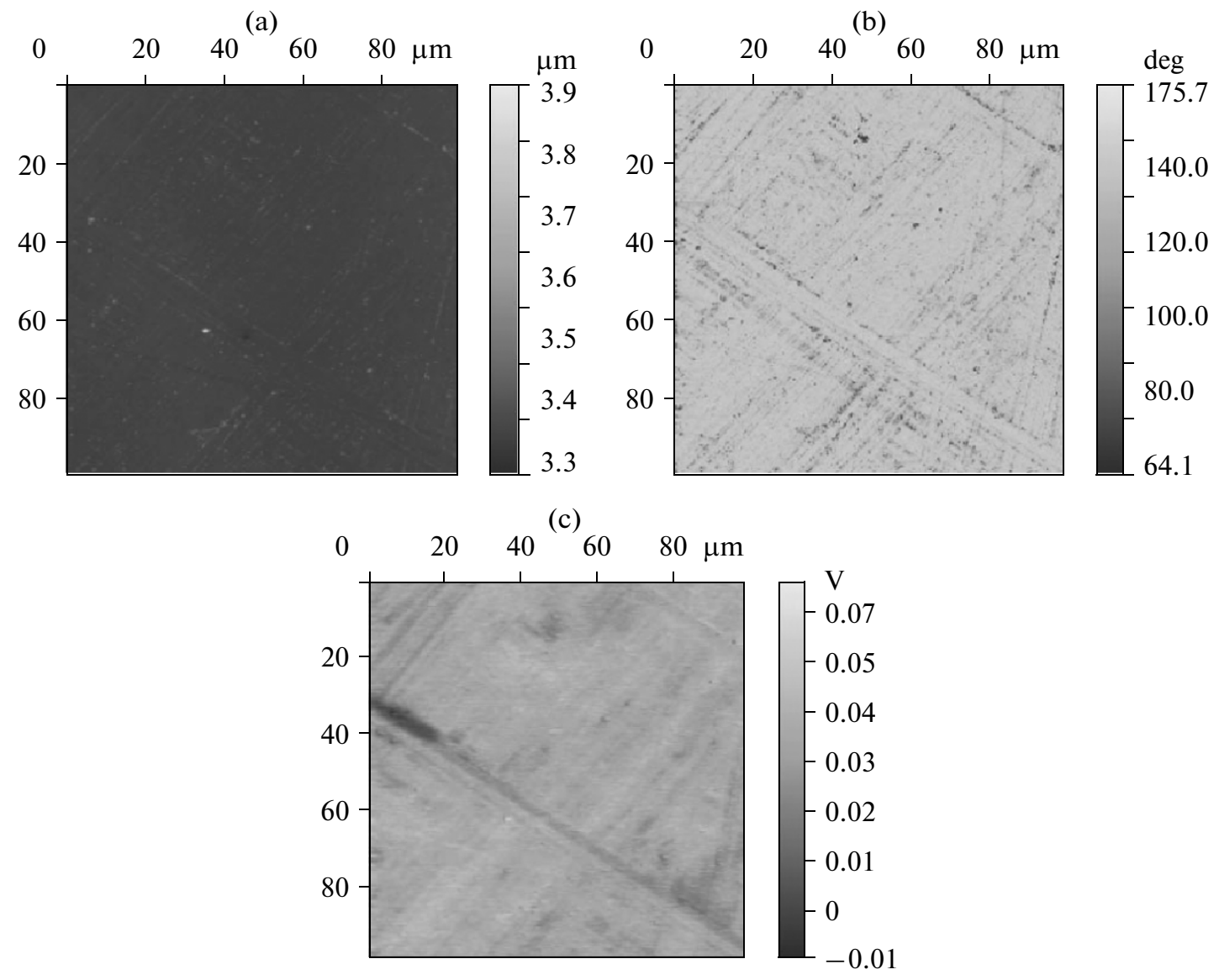

Fig. 2. AFM images of surfaces for specimens of group I. The scanning area is $100 \times 100 \mu \mathrm{m}$.

ment, is revealed on the surface. The phase contrast of the surface represents the distribution of the mechanical properties of the surface. The phase contrast considerably changes at the location of the deep scratches. In our opinion, this is related to water vapor absorption from the ambient air. This assumption is confirmed by images of the surface potential relief (Fig. 2b) that demonstrate a slight change in the surface potential at the scratch locations.

Figure 3 shows images of the surfaces of the specimens of group I obtained at a larger magnification. Spherical flaws, which are evidently abrasive particles embedded into the titanium surface during its polishing, are detected on the shown images of the surface relief (Fig. 3a), phase contrast (Fig. 3b), and surface potential (Fig. 3c). However, a detailed study of this issue requires additional investigation.

Table 1 presents the results of measuring the roughness of a polished titanium substrate that were obtained using the Gwiddion 2.25 software complex for processing AFM images. The measured parameters of the surface roughness for specimens of group I allow the obtained surfaces to be classified as belonging to the 13th roughness class.

Table 2 presents the results of measuring the parameters of the surface potential for specimens of group I.

Table 1. Roughness parameters for specimens of group I

\begin{tabular}{c|c|c|c|c|c}
\hline $\begin{array}{c}\text { Size of the } \\
\text { scanned area, } \\
\mu \mathrm{m}\end{array}$ & $\begin{array}{c}\text { Mean } \\
\text { arithmetic devia- } \\
\text { tion of the } \\
\text { surface profile } \\
R a, \mathrm{~nm}\end{array}$ & $\begin{array}{c}\text { Height } \\
\text { of irregularities } \\
\text { of the profile over } \\
\text { ten points } \\
R z, \mathrm{~nm}\end{array}$ & $\begin{array}{c}\text { Maximum } \\
\text { height of the } \\
\text { roughness } \\
\text { profile } \\
P t, \mathrm{~nm}\end{array}$ & $\begin{array}{c}\text { Mean } \\
\text { maximum depth } \\
\text { of roughness } \\
\text { valleys } \\
R v m, \mathrm{~nm}\end{array}$ & $\begin{array}{c}\text { Mean } \\
\text { maximum height } \\
\text { of roughness } \\
\text { peaks } \\
R p m, \mathrm{~nm}\end{array}$ \\
\hline $100 \times 100$ & 6.32 & 96.1 & 95.97 & 12.47 & 38.82 \\
\hline
\end{tabular}


(a)

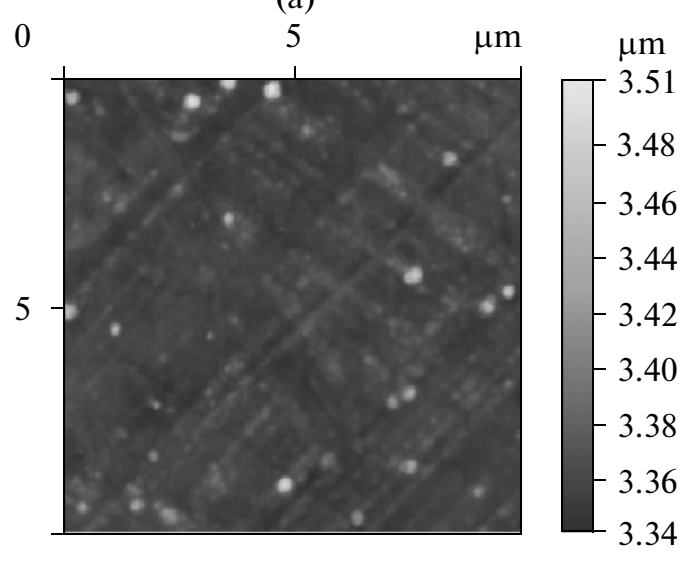

(b)

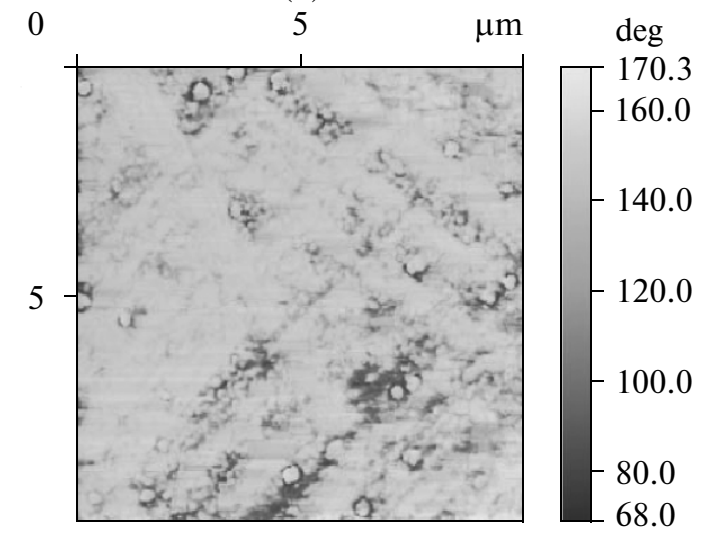

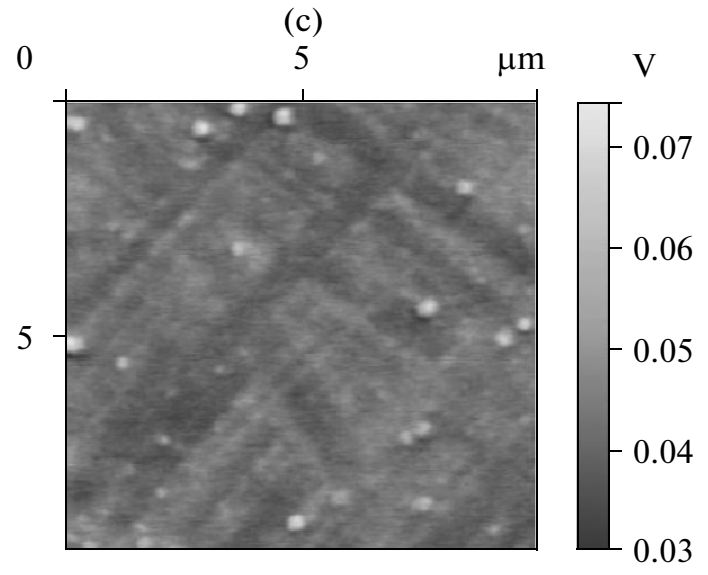

Fig. 3. AFM images of surfaces for specimens of group I. The scanning area is $10 \times 10 \mu \mathrm{m}$.

The analysis of the obtained data allows us to state that the potential of specimens of group I is virtually zero; in our opinion, insignificant potential changes are associated with the absorption of water vapors by the substrate and slight oxidation of the substrate.

Figure 4 shows images of the surface relief (a), phase contrast (b), and surface potential relief (c) for specimens of group II. The analysis of the obtained images allows us to conclude that the CP coating formed on a polished titanium substrate by the RFMS method substantially modifies the substrate microrelief; individual asperities and craters with a size of $\sim 20 \mu \mathrm{m}$ are observed on the coating. This is associated with the mechanism of the atomic growth of CP coatings. The analysis of the phase contrast allows us to conclude that the coating completely covers the titanium substrate and insulates it from external actions. Study of the surface potential of the CP coating indicates that its values increase. This is especially pronounced at asperities of coatings, which are crystallization centers and centers of growth of a thin CP film.

Table 2. Parameters of the surface potential for specimens of group I

\begin{tabular}{c|c|c|c|c}
\hline $\begin{array}{c}\text { Size } \\
\text { of the scanned area, } \\
\mu \mathrm{m}\end{array}$ & $\begin{array}{c}\text { Mean } \\
\text { arithmetic deviation } \\
\text { of the potential } \\
\text { profile } \\
\varphi_{a}, \mathrm{~V}\end{array}$ & $\begin{array}{c}\text { Mean } \\
\text { value of the surface } \\
\text { potential } \\
U_{\mathrm{m}}, \mathrm{V}\end{array}$ & $\begin{array}{c}\text { Minimum } \\
\text { value of the surface } \\
\text { potential, } \\
U_{\min }, \mathrm{V}\end{array}$ & $\begin{array}{c}\text { Maximum } \\
\text { value of the surface } \\
\text { potential } \\
U_{\text {max }}, \mathrm{V}\end{array}$ \\
\hline $100 \times 100$ & 0.00392 & 0.03311 & -0.0092 & 0.0655 \\
\hline
\end{tabular}



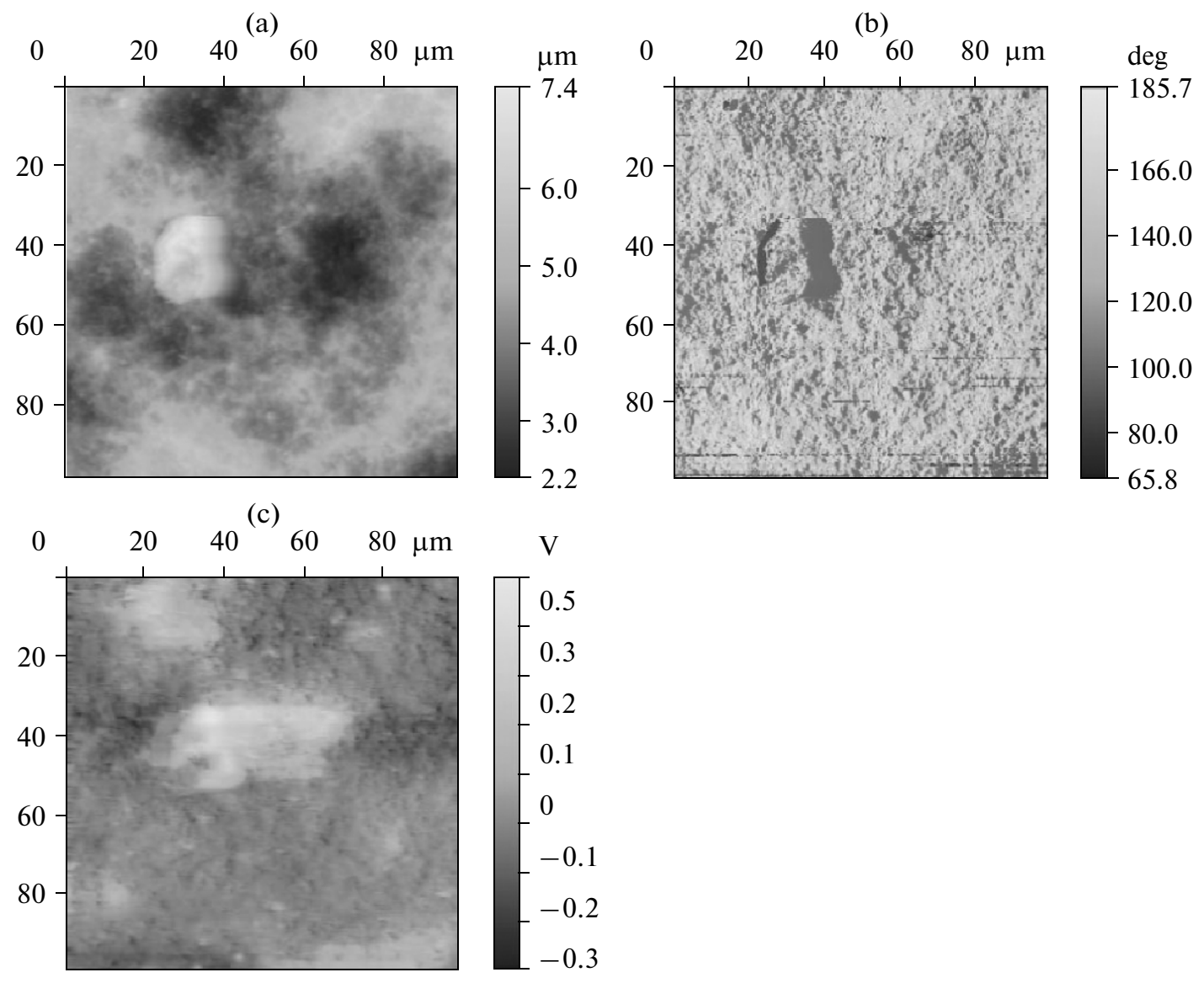

Fig. 4. AFM images of surfaces for specimens of group II. The scanning area is $100 \times 100 \mu \mathrm{m}$.

Study of the relief of CP coatings at large magnifications (Fig. 4) confirms the hypothesis of the mechanism of atomic growth of thin CP films, since the boundaries of grains with a size of $\sim 0.3 \mu \mathrm{m}$ and a height of $0.19 \mu \mathrm{m}$ are easily distinguished in the relief and phase-contrast patterns.

Table 3 presents the results of measuring the roughness of a polished titanium substrate with a CP coating. On the basis of these data, it can be concluded that the CP coating considerably modifies the microrelief of a polished titanium substrate, its roughness parameters increase, and the formed coatings belong to the tenth class. An increase in the coating roughness in the microscale may be an additional stimulating factor for the growth of tissues, e.g., via the attachment and proliferation of osteogenic cells on the surface of the CP coating [11].

Table 4 presents the results of measuring the parameters of the surface potential of a titanium substrate with a CP coating.

Note that CP coatings that were formed by the RFMS method on titanium substrates increase the average values of the surface potential by a value of up to $0.052 \mathrm{~V}$. In this case, apart from the regions with pos-

Table 3. Roughness parameters for specimens of group II

\begin{tabular}{c|c|c|c|c|c}
\hline $\begin{array}{c}\text { Size } \\
\text { of the scanned } \\
\text { area, } \\
\mu \mathrm{m}\end{array}$ & $\begin{array}{c}\text { Mean } \\
\text { arithmetic devia- } \\
\text { tion of the } \\
\text { surface profile } \\
R a, \mathrm{~nm}\end{array}$ & $\begin{array}{c}\text { Height } \\
\text { of irregularities } \\
\text { of the profile over } \\
\text { ten points } \\
R z, \mathrm{~nm}\end{array}$ & $\begin{array}{c}\text { Maximum } \\
\text { height of the } \\
\text { roughness } \\
\text { profile } \\
P t, \mathrm{~nm}\end{array}$ & $\begin{array}{c}\text { Mean } \\
\text { maximum depth } \\
\text { of roughness val- } \\
\text { leys } \\
R v m, \mathrm{~nm}\end{array}$ & $\begin{array}{c}\text { Mean } \\
\text { maximum height } \\
\text { of roughness } \\
\text { peaks } \\
R p m, \mathrm{~nm}\end{array}$ \\
\hline $100 \times 100$ & 152 & 801 & 1622 & 440 & 429 \\
\hline
\end{tabular}


Table 4. Parameters of the surface potential for specimens of group II

\begin{tabular}{c|c|c|c|c}
\hline $\begin{array}{c}\text { Size } \\
\text { of the scanned area, } \\
\mu \mathrm{m}\end{array}$ & $\begin{array}{c}\text { Mean arithmetic } \\
\text { deviation of the } \\
\text { potential profile } \\
\varphi_{a}, \mathrm{~V}\end{array}$ & $\begin{array}{c}\text { Mean value } \\
\text { of the surface } \\
\text { potential } \\
U_{\mathrm{m}}, \mathrm{V}\end{array}$ & $\begin{array}{c}\text { Minimum value } \\
\text { of the surface } \\
\text { potential, } \\
U_{\text {min }}, \mathrm{V}\end{array}$ & $\begin{array}{c}\text { Maximum value } \\
\text { of the surface } \\
\text { potential } \\
U_{\text {max }}, \mathrm{V}\end{array}$ \\
\hline $100 \times 100$ & 0.133 & 0.052 & -0.395 & 0.642 \\
\hline
\end{tabular}

Table 5. Surface roughness parameters for specimens of group III

\begin{tabular}{c|c|c|c|c|c}
\hline $\begin{array}{c}\text { Size } \\
\text { of the scanned } \\
\text { area, } \mu \mathrm{m}\end{array}$ & $\begin{array}{c}\text { Mean } \\
\text { arithmetic } \\
\text { deviation of the } \\
\text { surface profile } \\
R a, \mathrm{~nm}\end{array}$ & $\begin{array}{c}\text { Height } \\
\text { of irregularities } \\
\text { of the profile over } \\
\text { ten points } \\
R z, \mathrm{~nm}\end{array}$ & $\begin{array}{c}\text { Maximum height } \\
\text { of the roughness } \\
\text { prof } P t, \mathrm{~nm}\end{array}$ & $\begin{array}{c}\text { Mean } \\
\text { maximum depth } \\
\text { of roughness val- } \\
\text { leys } R v m, \mathrm{~nm}\end{array}$ & $\begin{array}{c}\text { Mean } \\
\text { maximum height } \\
\text { of roughness } \\
\text { peaks } R p m, \mathrm{~nm}\end{array}$ \\
\hline $100 \times 100$ & 16.2 & 92.2 & 231.3 & 52.5 & 49.9 \\
\hline
\end{tabular}

itive charges, microscopic regions with negative charges of up to $0.395 \mathrm{~V}$ relative to the ground are detected.

Figure 6 shows images obtained in AFM measurements of the surface relief (a), phase contrast (b), and surface potential relief (c) of specimens of group III.

The analysis of the AFM images of the surface relief, phase contrast, and surface potential allows us to conclude that the formed surface of the TFE/VDF polymer coating is a rather homogeneous film with a negative surface potential. At large magnifications, it can be revealed (Fig. 7) that the TFE/VDF coating

(a)
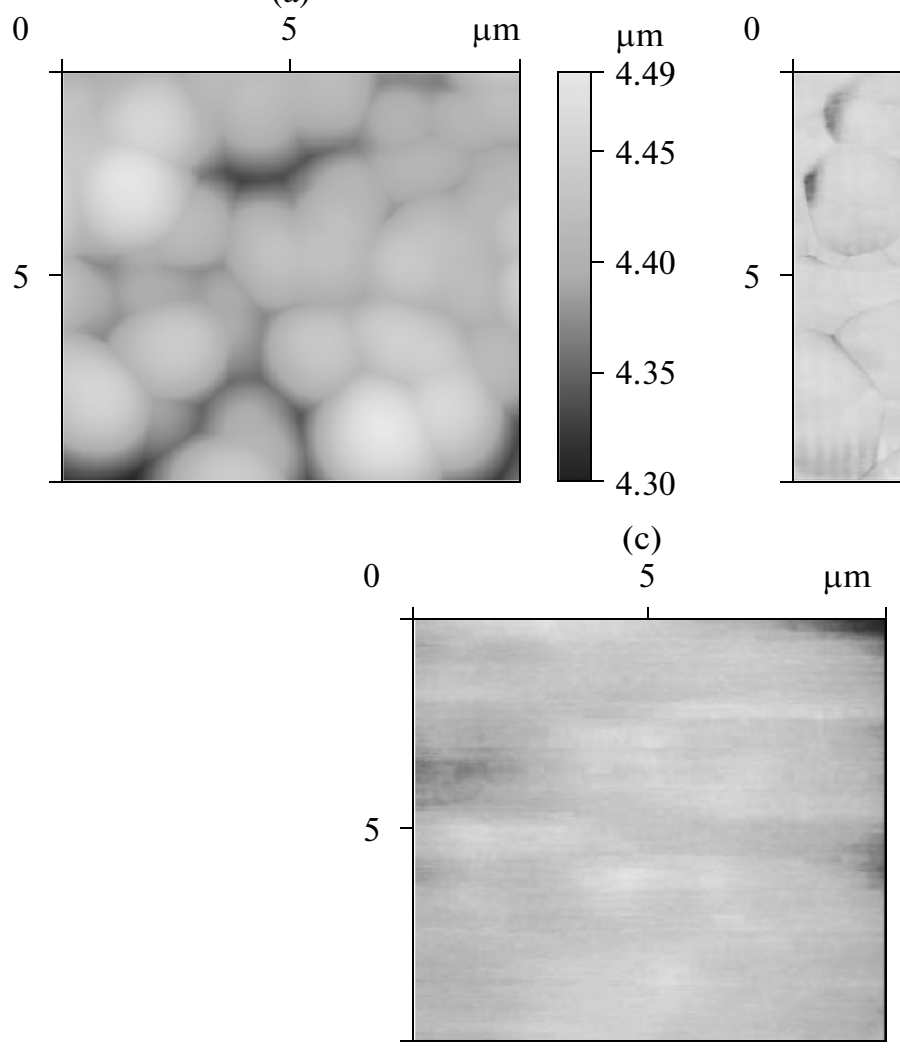

(b)
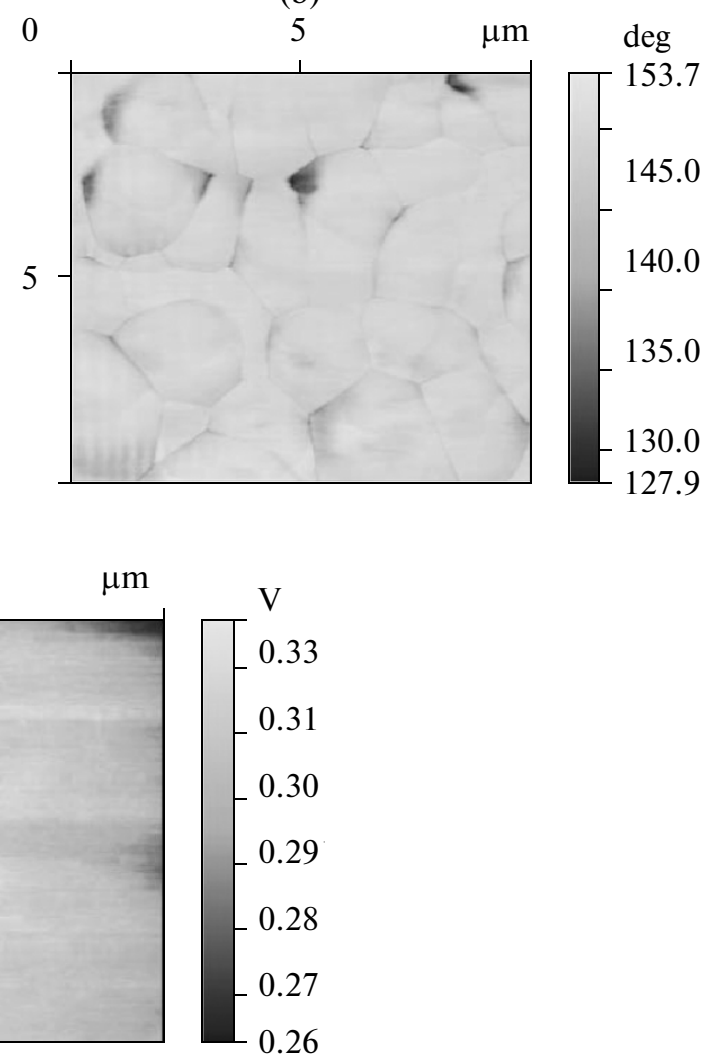

Fig. 5. AFM images of surfaces for specimens of group II. The scanning area is $1 \times 1 \mu \mathrm{m}$. 

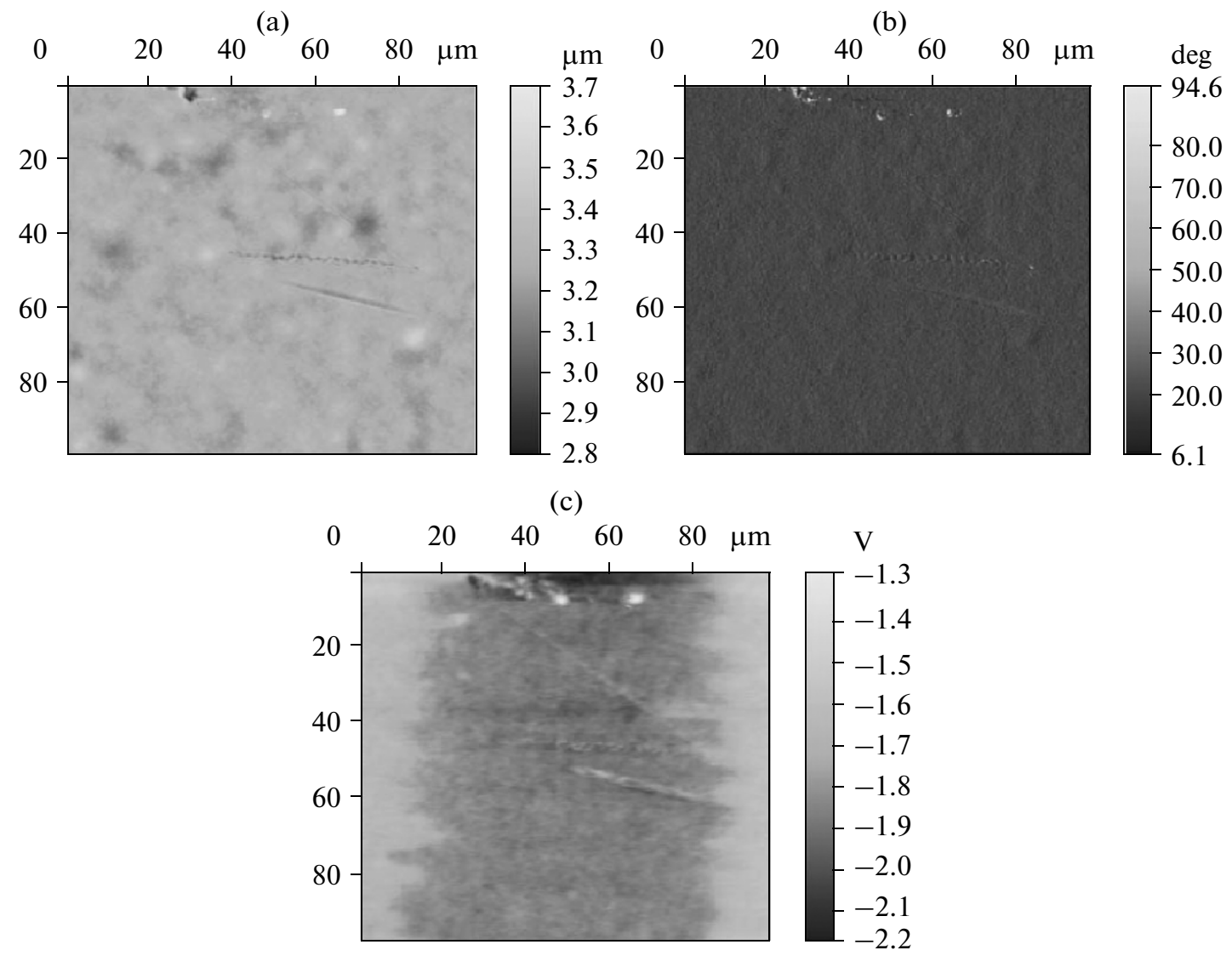

Fig. 6. AFM images of surfaces for specimens of group III. The scanning area is $100 \times 100 \mu \mathrm{m}$.

film is formed as an ordered structure of polymer spherulites, which are polymer areas with different degrees of crystallinity, thus corresponding to the present-day concepts of the TFE/VDF copolymer structure [12].

Table 5 presents the results of measuring the surface roughness of the TFE/VDF coating. The analysis of the obtained data indicates that the polymer coating makes it possible to smooth flaws that arise during the mechanical treatment of the titanium substrate; the obtained coatings belong to the 13th class. Such coatings can be used as biomaterials to which the adhesion of cells is low, i.e., the tromboresistive coatings of vascular stents, for which, in addition to a high surface finish class, a negative surface potential is required. It is known that the set of these requirements provides the reliable functioning of intravascular stents at a minimum percentage of repeated surgical interventions [13].

Table 6 presents the results of measuring the parameters of the surface potential for specimens of group III.

Figure 8 shows images obtained in AFM measurements of the surface relief (a), phase contrast (b), and surface potential relief (c) for specimens of group IV. The coating completely covers the polymer layer; this is confirmed by the phase-contrast distribution.

Table 6. Parameters of the surface potential for specimens of group III

\begin{tabular}{c|c|c|c|c}
\hline $\begin{array}{c}\text { Size } \\
\text { of the scanned area, } \\
\mu \mathrm{m}\end{array}$ & $\begin{array}{c}\text { Mean } \\
\text { arithmetic deviation } \\
\text { of the potential } \\
\text { profile } \varphi_{a}, \mathrm{~V}\end{array}$ & $\begin{array}{c}\text { Mean } \\
\text { value of the surface } \\
\text { potential } U_{\mathrm{m}}, \mathrm{V}\end{array}$ & $\begin{array}{c}\text { Minimum } \\
\text { value of the surface } \\
\text { potential, } U_{\min }, \mathrm{V}\end{array}$ & $\begin{array}{c}\text { Maximum } \\
\text { value of the surface } \\
\text { potential } U_{\text {max }}, \mathrm{V}\end{array}$ \\
\hline $100 \times 100$ & -0.082 & -1.82 & -2.178 & -1.272 \\
\hline
\end{tabular}


(a)

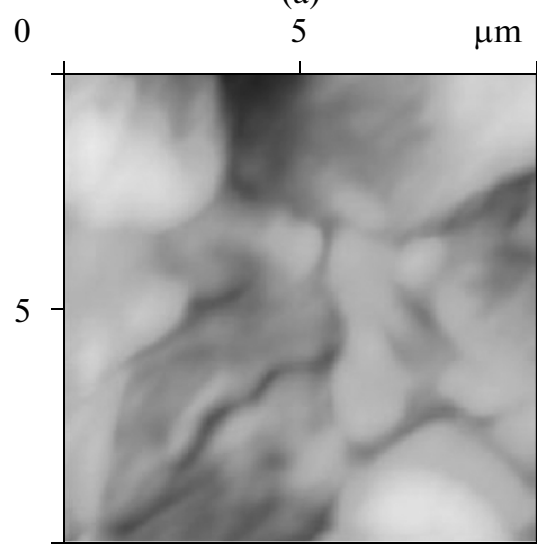

0

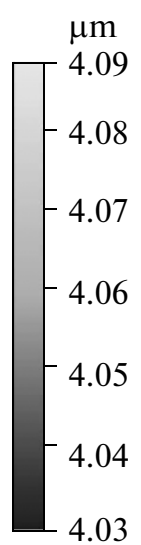

(c)

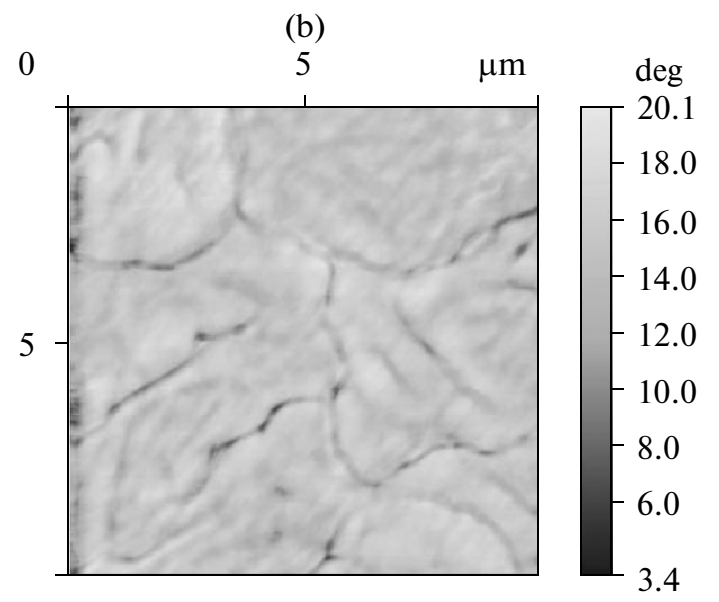

3.4

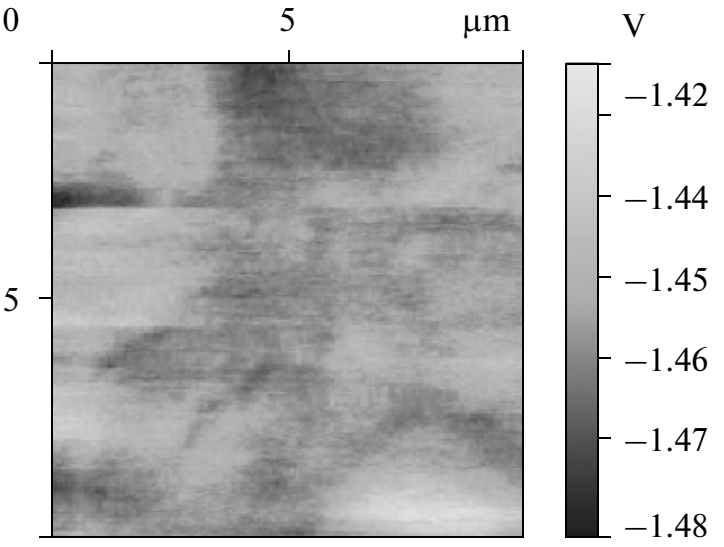

Fig. 7. AFM images of surfaces for specimens of group III. The scanning area is $1 \times 1 \mu \mathrm{m}$.

It can be observed at high magnifications that CP coatings that are formed by the method of RFMS of a CP target on a polymer substrate are similar in many aspects to coatings that are formed on polished titanium substrates and correspond to a conglomerate consisting of individual CP grains with a size of $\sim 0.3 \mu \mathrm{m}$. This is especially pronounced in the image of the phase contrast of the CP coating. On this basis, it can be assumed that the material of the substrate on which an RFMS coating is formed has no appreciable effect on the parameters of a CP coating.

The analysis of images of the surface potential of a CP coating and the data from Table 7 demonstrate a substantial decrease in the negative potential of the initial polymer substrate after depositing a CP coating. This is probably related to the fact that a ceramic-like CP coating is a $p$-type semiconductor with a wide energy gap (approximately $4 \mathrm{eV}$ ) [14]. This was determined by the method of exoelectron emission, which is sensitive to the presence of flaws in thin surface layers.

The use of this method allowed us to establish that a nanostructural CP surface is characterized by a high level of defectiveness. Moreover, a part of the flaws are electron-hole trapping centers that carry electric charges. As a result of different mobilities of electrons and holes, these localized charges participate in the formation of a double electrical layer and may change the surface potential [15]. As a whole, it can be

Table 7. Parameters of the surface potential for specimens of group IV

\begin{tabular}{c|c|c|c|c}
\hline $\begin{array}{c}\text { Size } \\
\text { of the scanned area, } \\
\mu \mathrm{m}\end{array}$ & $\begin{array}{c}\text { Mean } \\
\text { arithmetic deviation } \\
\text { of the potential } \\
\text { profile } \varphi_{a}, \mathrm{~V}\end{array}$ & $\begin{array}{c}\text { Mean } \\
\text { value of the surface } \\
\text { potential } U_{\mathrm{m}}, \mathrm{V}\end{array}$ & $\begin{array}{c}\text { Minimum } \\
\text { value of the surface } \\
\text { potential, } U_{\min }, \mathrm{V}\end{array}$ & $\begin{array}{c}\text { Maximum } \\
\text { value of the surface } \\
\text { potential } U_{\max }, \mathrm{V}\end{array}$ \\
\hline $100 \times 100$ & -0.042 & -0.526 & -1.014 & -0.054 \\
\hline
\end{tabular}




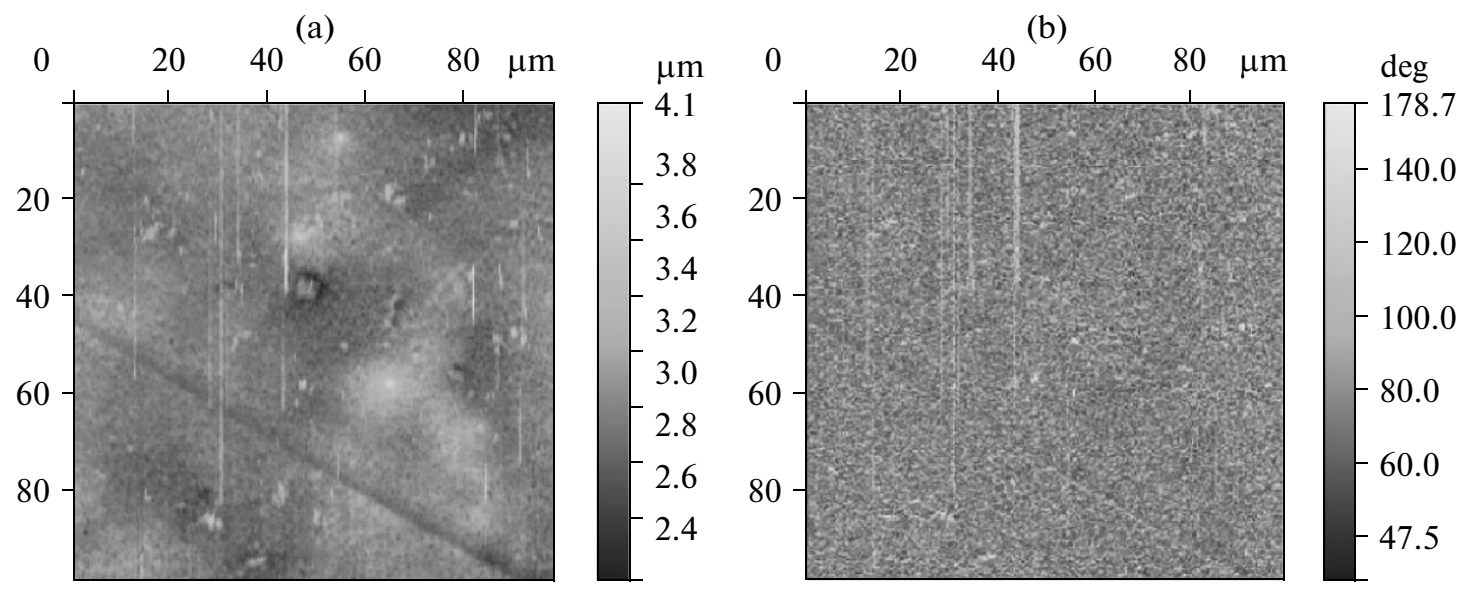

(c)

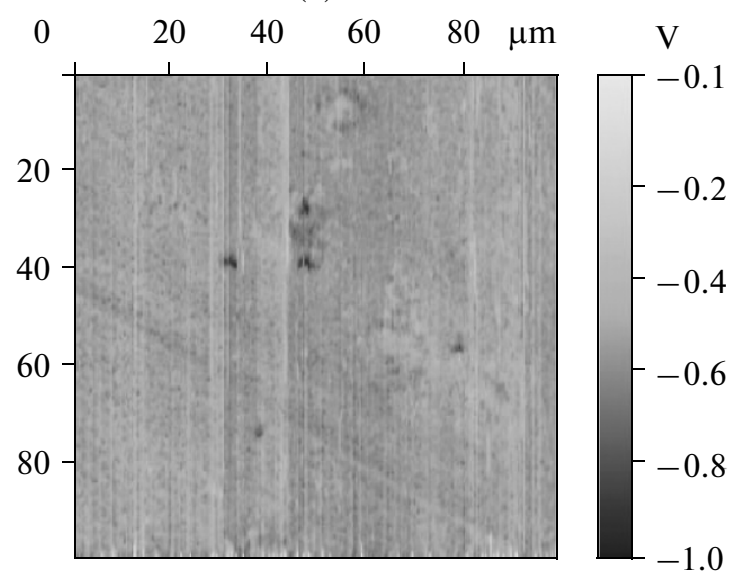

Fig. 8. AFM images of surfaces for specimens of group IV. The scanning area is $100 \times 100 \mu \mathrm{m}$.

concluded that CP coatings formed by the RFMS method have a positive surface potential, thus conforming to the data from [16].

Table 8 presents the results of measuring the surface roughness of the TFE/VDF polymer coating covered with a CP coating, which was formed by the RFMS method.

The data on the coating roughness that are listed in Table 8 allow one to conclude that a CP coating substantially modifies the microrelief of a polymer coating, as is also observed for a polished titanium substrate. The mean arithmetic deviation $R a$ of the surface profile increases by a factor of 2.9 , and the maximum height of the surface roughness profile Pt increases by a factor of 3.9. The thus-formed coatings belong to the 11th class of roughness.

Table 8. Roughness parameters for specimens of group IV

\begin{tabular}{c|c|c|c|c|c}
\hline $\begin{array}{c}\text { Size } \\
\text { of the scanned } \\
\text { area, } \mu \mathrm{m}\end{array}$ & $\begin{array}{c}\text { Mean } \\
\text { arithmetic } \\
\text { deviation of the } \\
\text { surface profile } \\
R a, \mathrm{~nm}\end{array}$ & $\begin{array}{c}\text { Height } \\
\text { of irregularities } \\
\text { of the profile over } \\
\text { ten points } R z, \mathrm{~nm}\end{array}$ & $\begin{array}{c}\text { Maximum height } \\
\text { of the roughness } \\
\text { profile } P t, \mathrm{~nm}\end{array}$ & $\begin{array}{c}\text { Mean } \\
\text { maximum depth } \\
\text { of roughness } \\
\text { valleys } R v m, \mathrm{~nm}\end{array}$ & $\begin{array}{c}\text { Mean } \\
\text { maximum height } \\
\text { of roughness } \\
\text { peaks } R p m, \mathrm{~nm}\end{array}$ \\
\hline $100 \times 100$ & 47.2 & 376 & 918.2 & 141.2 & 152.2 \\
\hline
\end{tabular}




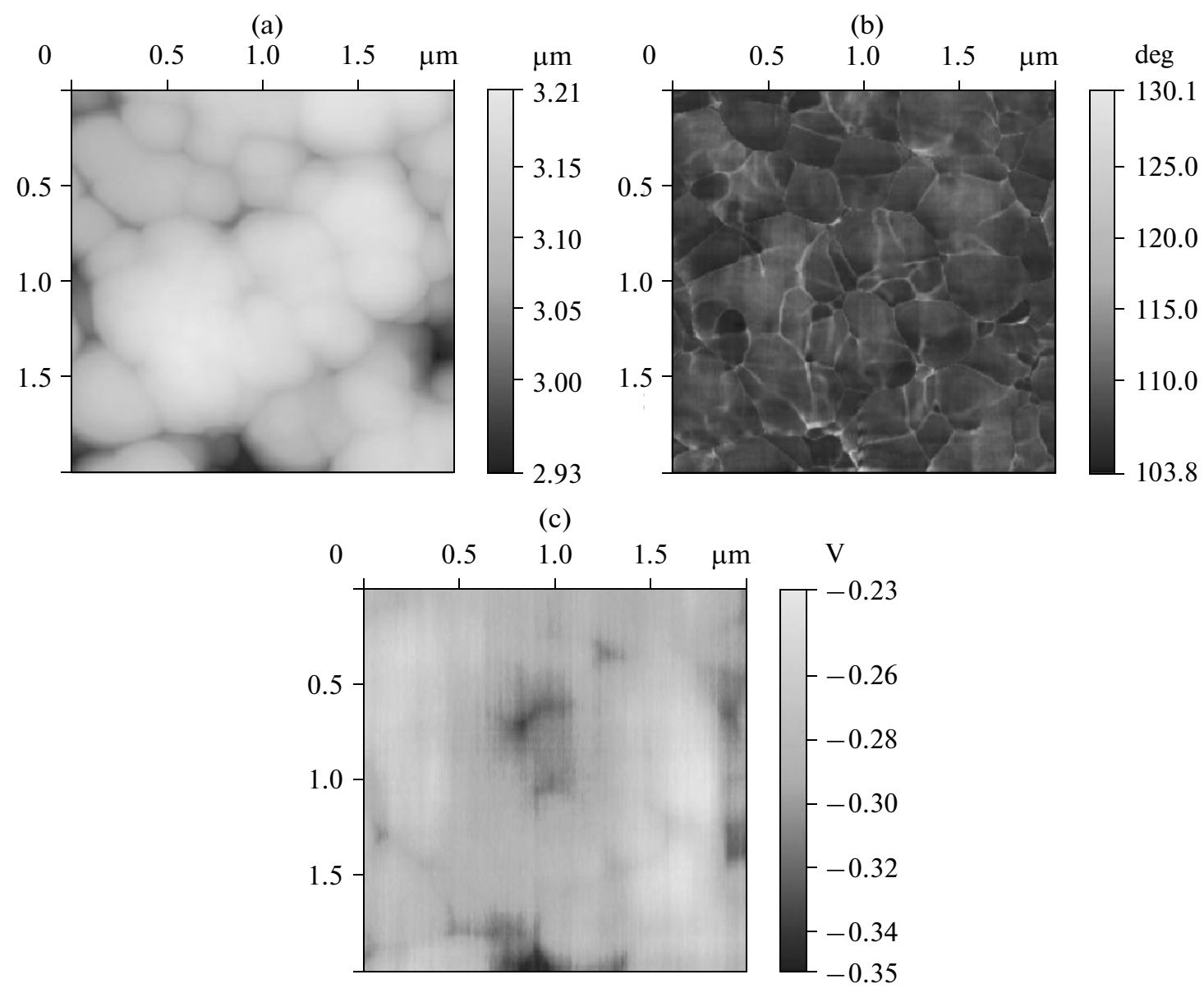

Fig. 9. AFM images of surfaces for specimens of group IV. The scanning area is $2 \times 2 \mu \mathrm{m}$.

\section{CONCLUSIONS}

(1) The use of the AFM methods allows quantitative evaluation of the surface roughness parameters and the distribution of the surface potential of biocoatings, thus yielding substantial data for determining the field of application of such coatings.

(2) Using the AFM method, it was shown that the substrate type (polished titanium or a polymer coating) has an insignificant effect on the parameters of CP coatings that are formed by the method of RFMS of a hydroxyapatite target. It was shown that high-quality CP coatings can be formed by the RFMS method on the surfaces of polymer materials intended for medical use.

(3) It was shown that the deposition of coatings by the RFMS method increases the surface roughness of polymer and metal materials, thus being a stimulating factor for attachment and proliferation of osteogenic cells.

(4) Using the Kelvin method, it was shown that CP coatings that are formed by the method of RFMS of a hydroxyapatite target modify the surface potential by shifting it to the positive region relative to the ground.

\section{ACKNOWLEDGMENTS}

This study was supported by the Analytical Departmental Targeted Program Development of the Scientific Potential of the Higher School for 2009-2011 (project no. 3.659.2011, registered no. 2.1.1/14204) and the Federal Targeted Program Investigations and Design Works in Priority Trends of the Development of Scientific and Technological Complex in Russia, 2007-2012 (GK 6.512.11.2179). 


\section{REFERENCES}

1. Aronov, A.M., Pichugin, V.F., Eshenko, E.V., Ryabtseva, M.A., Surmenev, R.A., Tverdokhlebov, S.I., and Shesterikov, E.V., Thin Calcium Phosphate Coatings Obtained by the Radio Frequency Magnetron Sputtering Method and Prospects for Their Use in Medical Technology, Meditsin. Tekhn., 2008, no. 3, pp. 18-22.

2. Khlusov, I.A., Nechaev, K.A., Shevtsova, N.M., Khlusova, M.Yu., Dvornichenko, M.V., Zaitsev, K.V., Kolokol'tsova, T.D., Bol'basov, E.N., Sharkeev, Yu.P., Legostaeva, E.V., and Saburina, I.N., On Fibroplasticlike Cells in Human Peripheral Blood, Cell Transplantology and Tissue Engineering, 2010, vol. 5, no. 4.

3. Aronov, A.M., Bol'Basov E.N., Guzeev V.V., Dvornichenko M.V., Tverdokhlebov S.I., Khlusov I.A. Biological Composites Based on Fluoropolymers with Hydroxyapatite for Intramedullary Implants, Biomedical Engineering, 2010, vol. 44, no. 3, pp. 108-113.

4. Rossnagel, S.M., Sproul, W.D., and Legg, K.O., Sputter Deposition. Opportunities for Innovation, Advanced Surface Engineering, Switzerland, Technomic Publishing Co, 1995.

5. Khlusov, I.A., Karlov, A.V., Sharkeev, Yu.P., et al., Osteogenic Potential of Mesenchyme Bone Marrow Stem Cell in situ: Role of Physicochemical Properties of Artificial Surfaces, Kletoch. Tekhnol. Biol. Medits. 2005, no. 3, pp. 164-173.

6. Karlov, A.V. and Shakhov, V.P., Sistemy vneshnei fiksatsii i regulyatornye mekhanizmy optimal'noi biomekhaniki (Systems of External Fixation and Regulatory Mechanisms of optimal Biomechanics), Tomsk: STT, 2001.

7. Levin, M., Large-Scale Biophysics: Ion Flows and Regeneration, Trends in Cell Biology, 2007, vol. 17, pp. 261270 .

8. McCaig, C.D., Rajnicek, A.M., Song, B., and Zhao, M., Controlling Cell Behavior Electrically: Current Views and Future Potential, Physiological Reviews, 2005, vol. 85, pp. 943-978.

9. Mironov, V.L., Osnovy skaniruyushchei zondovoi mikroskopii (Fundamentals of Scanning Probe Microscopy), Nizhnii Novgorod, 2004.

10. Popok, V.N., Kalabukhov, A., Gunnarsson, R., Lemeshko, S., and Claeson, T., Winkler Dag, Kelvin Probe Force Microscopy Study of LaAlO3/SrTiO3 Heterointerfaces, J. Adv. Microsc. Res., 2010, vol. 5, pp. 1-5.

11. Karlov, A.V. and Khlusov, I.A., Dependence of Reparative Osteogenesis Processes on the Surface Properties of Implants for Osteosynthesis, Genii Ortopedii, 2003, no. 3, pp. 46-51.

12. Panshin, Yu.A., Malkevich, S.G., and Dunaevskaya, Ts.S., Ftoroplasty (Fluoroplastics), Leningrad: Khimiya, 1978.

13. Sosudistoe $i$ vnutriorgannoe stentirovanie. Rukovodstvo (Vascular and Intraorganic Stenting), Moscow: Izdatel'skii Dom GRAAL, 2003.

14. Rosenman, G. and Aronov, D., Wettabiligy Engineering and Bioactivation of Hydroxyapatite Nanoceramics, Int. Tech. Proc. Nanotech. Conf., Boston, 2006, vol. 2, pp. 91-94.

15. Aronov, D. and Rosenman, G., Traps States Spectroscopy Studies and Wettability Modification of Hydroxyapatite Nano-Bio-Ceramics, J. Appl. Phys., 2007, vol. 101, p. 034701.

16. Khlusov, I.A., Pichugin, V.F., Gostishchev, E.A., Sharkeev, Yu.P., et al., Influence of Physical, Chemical, and Biological Manipulations on the Surface Potential of Calcium Phosphate Coatings on Metal Substrates, Byull. Sibir. Med., 2011, no. 3, pp. 72-81. 